\title{
Integrated Briquetting Plant: Study for Maichew Particle Board Factory
}

\author{
Temesgen Gebrekidan, Yonas Zeslase Belete \\ Department of Chemical Engineering, Adigrat University, Adigrat, Ethiopia
}

Email address:

temekidan@gmail.com (T. Gebrekidan),yonbelete7@gmail.com (Y. Z. Belete)

To cite this article:

Temesgen Gebrekidan, Yonas Zeslase Belete. Integrated Briquetting Plant: Study for Maichew Particle Board Factory. Science Journal of Energy Engineering. Vol. 3, No. 3, 2015, pp. 11-22. doi: 10.11648/j.sjee.20150303.11

\begin{abstract}
Biomass briquetting is a process which converts agro residue and saw dust materials with low bulk density into a uniform size and more convenient households or industrial fuel product. The major advantages offered by biomass densification are related to handling improvement and increasing calorific value per unit volume. In general this process offers energy generation opportunity from any biomass residue. Maichew Particle Board Factory generates a huge amount of dust particles from its different lines which recovered using different cyclones. But this recovered waste doesn't use as a fuel for boiler or dryer and also not yet convert to any valuable product. It is simply disposed to the environment. Therefore, the objective of the project was to study an integrated briquetting plant for Maichew Particle Board Factory which converts the waste dust particle in to valuable product. This case study involved the overall energy review of Ethiopia and briquetting process in detail. According to the selection of appropriate technology which converts the eucalyptus dust to high quality briquette fuel screw press extruder with a pre heater and heated die coils has been chosen. In addition the amount of energy required to convert the dust particle to briquettes is also evaluated. Based on the results of this study, the economic evaluation of the integrated briquetting plant for Maichew Particle Board is feasible besides to its socio environmental benefits. It is an investment which can recover its capital with almost two years.
\end{abstract}

Keywords: Biomass Energy, Biomass Briquetting, Waste Dust Particle

\section{Introduction}

Historically, biomass has been a major source of household's energy in Ethiopian. Biomass meets the cooking energy needs of most rural households and half of the urban household's demands. Despite significant penetration of commercial energy in Ethiopia during last few decades, biomass continues to dominate energy supply in rural and traditional sectors. Biomass energy constitutes wood fuels (including charcoal, and wood wastes), crop residues (such as coffee husk, bagasse, rice husk and crop stalks) and animal dung (including biogas) [8,10]. Ethiopia's energy system is characterized mainly by biomass fuel supply, with households being the greatest energy consumers. The total percentage total energy consumption in 1998 is estimated accordingly the following table.

From this total, biomass fuels accounted for 94\% (77\% from wood fuels, $17 \%$ from agricultural residues, dung and charcoal), petroleum fuels for $5 \%$ and electricity for less than $1 \%$ of supplies. The household sector takes up nearly $90 \%$ of the total energy supplies.

Table 1. Total Energy Consumption in Ethiopia in 1998.

\begin{tabular}{ll}
\hline Energy Type & Percentage (\%) \\
\hline Biomass & 94 \\
Petroleum & 5 \\
Electricity & 1 \\
Total & 100 \\
\hline
\end{tabular}

This dependence on biomass resources has been detrimental to their sustainability and adverse to the environment. The overall dependency of majority of the population on the charcoal and fuels wood as energy source has brought in its wake the threat of deforestation and this leads to decrease the soil fertility. This impasse can be sustainably resolved through the introduction and wide dissemination of new and renewable energy technologies. Such as:

- Use of densified agricultural residues for fuel;

- Demonstration projects on biogas, solar energy and thermal; 
- Improved stoves;

- Improved charcoal production technologies; and

- Trials on fast growing tree species for fuel.

Processing of agricultural residue to produce good quality house hold cooking fuels had started in the early 1990 after the investigation of the opportunities to use biomass residue at state farms and agro industries as the substitute for the fuel used in households and industries. And a pilot plant had erected in different governmental farms such as Diksis (wheat straw), Amibra (cotton stalk) and Shoa (bagasse) and so on. But these plants were not successful while operation due to the instability of the country in the civil war in 1980's and some technical failure such wear of the pressing machine and lack of skilled man power to operate the plants [1].

Maichew Particle Board Factory PLC is a private company established under EFFORT with the objectives of producing and supplying high quality three layer particle board products. The factory has annual production capacity of $40,000 \mathrm{~m} 3$. Its major standard raw material is eucalyptus tree. During processing there is 3360 ton per year emission of dust particles which is captured and collected using an exhaust system connected to a cyclone. But this recovered dust does not used as a fuel for boiler or dryer and also not yet convert to any valuable product. It is simply disposed to the compound and makes a load of materials within last three years operational period. It has been shown that this waste can be converted into valuable product which can bring an economic benefit and reduce the cost incurred on disposition of the dust particles.

Because of this reason, the objective of project studied an integrated briquetting plant which converts the above mentioned waste dust particles generates in Maichew Particle Board Factory to a valuable product so called briquetting.

\section{Literature Review}

\subsection{Agro Residue and Saw Dust as a Fuel Sources}

The shortage of fuel in many parts of the developing countries such as Ethiopia caused by an increasing shortage of traditional fuel (firewood, charcoal) creates a need for alternative sources of domestic fuel. Ethiopian has an agricultural based economy where all kind of tropical crops are in cultivation and residues such as coffee husk, cotton stalks, wheat straw, bagasse's, shells and nuts are major potential fuels used in many part of the country. Sawdust, a milling residue is also available in some quantity. Utilization of agricultural and forestry residues is often difficult due to their uneven characteristics, low density, inconvenient shape, high moisture content, low calorific value per unit volume, etc. are some of the hampering factors. This drawback can be overcome by means of densification, i.e. compaction of the residues into products of high density and regular shape. And further processing like carbonization (pyrolysis) is needed to transform the various types of organic waste into an acceptable form of domestic fuel [5].

Densification has aroused a great deal of interest worldwide in recent years as a technique of beneficiation of residues for utilization as energy source. Not only as ultimate solution for the problems of transportation, storage, and handling, but also the direct burning of loose biomass in conventional grates is associated with very low thermal efficiency and widespread air pollution.

\subsection{Biomass Briquetting (Densification)}

Biomass densification is processing of biomass byproducts such as agricultural and forest residues, sawdust, slabs, chips, etc. into uniform sized particles which can be compressed into wood-based fuel products. It is important to mention that biomass densification is simply a physical transformation that does not change the chemical composition of biomass. Thus, the calorific value of biomass is not affected by densification.

Nevertheless, since non-densified products exhibit lower bulk density than pellets and briquettes, fluffy materials (e.g. chips, sawdust, etc.) have lower energy density than densified products. The process offers the following advantages:

- The net calorific value per unit volume is increased,

- Easier handling,

- Lower transportation cost

- The fuel produced is uniform in size and quality,

- Disposal of residue is facilitated, and

- Environmental friendly fuels [7]

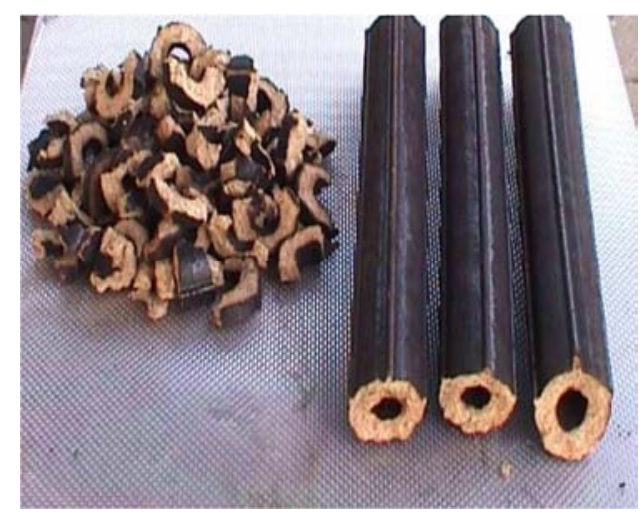

Figure 1. Sample of Briquette.

The process of transforming loosen biomass residue in to briquetting requires large amount energy consumption and sustainable supply of raw material. Raw materials for briquetting include waste from wood industries, loose biomass and other combustible waste products. On the basis of compaction, the briquetting technologies can be divided into:

- High pressure compaction,

- Medium pressure compaction with a heating device, and low pressure compaction with a binder.

In all these compaction techniques, solid particles are the starting materials. The individual particles are still identifiable to some extent in the final product. Briquetting and extrusion both represent compaction i.e., the pressing together of particles in a confined volume. If fine materials which deform under high pressure are pressed, no binders are 
required. The strength of such compacts is caused by van der Waals' forces, valence forces, or interlocking [10].

Natural components of the material may be activated by the prevailing high pressure forces to become binders. Some of the materials need binders even under high pressure conditions. The figure below shows some of the binding mechanisms.

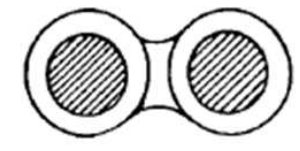

Hardening Binders

Highly viscous Binders Adsorption layer

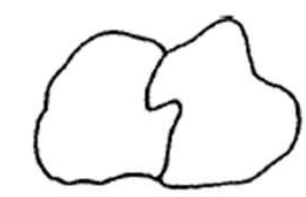

Form closed bonds (Interlocking)

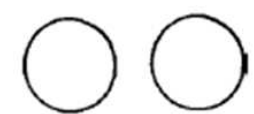

Molecular Forces (Van der Waal's Force)

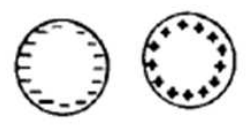

Electrostatic

Forces
Figure 2. Binding Mechanisms.

\subsection{Binding Mechanisms of Densification}

In order to understand the suitability of biomass for briquetting, it is essential to know the physical and chemical properties of biomass which also influence its behavior as a fuel. Physical properties of interest include moisture content, bulk density, void volume and thermal properties. Chemical characteristics of importance include the proximate and ultimate analysis, and higher heating value. The physical properties are most important in any description of the binding mechanisms of biomass densification. Densification of biomass under high pressure brings about mechanical interlocking and increased adhesion between the particles, forming intermolecular bonds in the contact area. In the case of biomass the binding mechanisms under high pressure can be divided into adhesion and cohesion forces, attractive forces between solid particles, and interlocking bonds [6].

High viscous bonding media, such as tar and other molecular weight organic liquids can form bonds very similar to solid bridges. Adhesion forces at the solid-fluid interface and cohesion forces within the solid are used fully for binding. Lignin of biomass/wood can also be assumed to help in binding in this way. Finely divided solids easily attract free atoms or molecules from the surrounding atmosphere. The thin adsorption layers thus formed are not freely movable. However, they can contact or penetrate each other. The softening lignin at high temperature and pressure condition form the adsorption layer with the solid portion. The application of external force such as pressure may increase the contact area causing the molecular forces to transmit high enough which increases the strength of the bond between the adhering partners. Another important binding mechanism is van der Waals' forces. They are prominent at extremely short distances between the adhesion partners. This type of adhesion possibility is much higher for powders. Fibers or bulky particles can interlock or fold about each other as a result forming interlocking or form-closed bonds. To obtain this type of bond, compression and shear forces must always act on the system. The strength of the resulting agglomerate depends only on the type of interaction and the material characteristics [9].

\subsection{Selection of Biomass Residue for Briquetting}

In addition to the availability of sustainable supply of raw material for the commercial briquetting plant there are many factors to be considered before a biomass residue qualifies for use as feedstock for briquetting. Some of the characteristics are the following.

\subsubsection{Low Moisture Content}

Moisture content should be as low as possible, generally in the range of $10-15 \%$. High moisture content will pose problems in grinding and excessive energy is required for drying.

\subsubsection{Ash Content and Composition}

Biomass residues normally have much lower ash content (except for rice husk with $20 \%$ ash) but their ashes have a higher percentage of alkaline minerals, especially potash. These constituents have a tendency to devolatilize during combustion and condense on tubes, especially those of super heaters. The ash content of some types of biomass are given in the below table.

Table 2. Ash Content of Selected Raw Materials.

\begin{tabular}{ll}
\hline Biomass & Ash content (\%) \\
\hline Saw dust & 1.3 \\
Coffee husk & 4.3 \\
Cotton shells & 4.6 \\
Rice husk & 22.4 \\
\hline
\end{tabular}

The ash content of different types of biomass is an indicator of slagging behavior of the biomass. Generally the greater the ash content, the greater the slagging behavior. But this does not mean that biomass with lower ash content will not show any slagging behavior. The temperature of operation, the mineral compositions of ash and their percentage combined determine the slagging behavior. If conditions are favorable, then the degree of slagging will be greater. Minerals like $\mathrm{SiO}_{2} \quad \mathrm{Na}_{2} \mathrm{O}$ and $\mathrm{K}_{2} \mathrm{O}$ are more troublesome.

\subsubsection{Flow Characteristics}

The material should be granular and uniform so that it can flow easily in bunkers and storage silos. The properties of the solids that are important to densification are:

- Flow ability and cohesiveness

- Particle size (too fine a particle means higher cohesion, causing poor flow)

- Surface forces (important to agglomeration for strength) [8]. 


\subsection{Biomass Briquetting Process}

Densification of biomass is a multi-operation manufacturing process. In general, the raw material has to fulfill some specific properties such as: size, uniformity, and moisture content before being densified. For this reason, the raw material needs to be pre-processed to achieve such conditions. This pre-processing stage may include size reduction operations (milling, grinding, chipping, etc.) and drying operations based the physical characteristics of the raw material. Once the raw material is prepared, it is compressed under high temperature and pressure conditions $[8,9]$.

\subsubsection{Size Reduction}

Size reduction refers to the reduction of any biomass by mechanical means into higher valued and relatively uniform bulk material to be used for subsequent processing. It is desired to reduce the given biomass particle size to the required final particle size with optimum energy consumption. Except saw dust other agricultural or forest residue should be crushed to $6-8 \mathrm{~mm}$ size with $10-20 \%$ fines to achieve optimum briquetting results. While many types of crushing and grinding equipment's are available in the market, for biomass materials, hammer mills are considered the most suitable. These are available in various sizes from a few $\mathrm{kg} / \mathrm{hr}$. to $10-15 \mathrm{TPH}$. Maintenance is rather routine and heavy in these machines and it is advisable not to operate these machines for more than 20 hours per day. Some hammer mills are symmetrical so the direction of the rotor can be reversed. In this case, more running time is possible without maintenance [7].

\subsubsection{Drying}

Drying refers to the reduction of the amount of moist of water in biomass. The main objective is to achieve uniform moisture content in the material at the end of the drying process. Drying is necessary in the production of briquettes due to technological reasons linked to the manufacturing process as well as storing and transportation reasons. Drying is normally not required for materials like coffee husk, groundnut shells and rice husk. If feed is wet and drying becomes essential, integrated drying cum disintegration should be carried out by using the hot flue gases from the thermic fluid preheating furnace. However, drying is essential for sawdust, wet coir pith, bagasse and bagasse pith and some other agro-residues like mustard stalk if their moisture content is greater than $10 \%$.

The types of drier employed for biomass materials are paddle indirect drier, flash, direct type, pneumatic or flash, and direct or indirect type rotary driers. Direct driers are those in which hot air or flue gases are intimately mixed with material and indirect ones are when heat is transferred to materials through a metallic surface and material is not mixed with the hot streams. Indirect driers are normally inefficient and require a large heat transfer area making the equipment bulky and expensive. Rotary driers are highly reliable but tend to be an order of magnitude more expensive than a flash drier, especially at a capacity less than 3-4 TPH.

All biomass materials are amenable to drying by flash driers with or without disintegration. Even though biomass materials are heat sensitive these can be satisfactorily dried at relatively high temperature because of short drying time. Most of the moisture is removed either in a disintegrator or at the entry point of the feed into the gas stream. Entry temperature of gases up to $300-400{ }^{\circ} \mathrm{C}$ can be conveniently employed even though the decomposition temperature of most biomass materials is between $250-350{ }^{\circ} \mathrm{C}$.

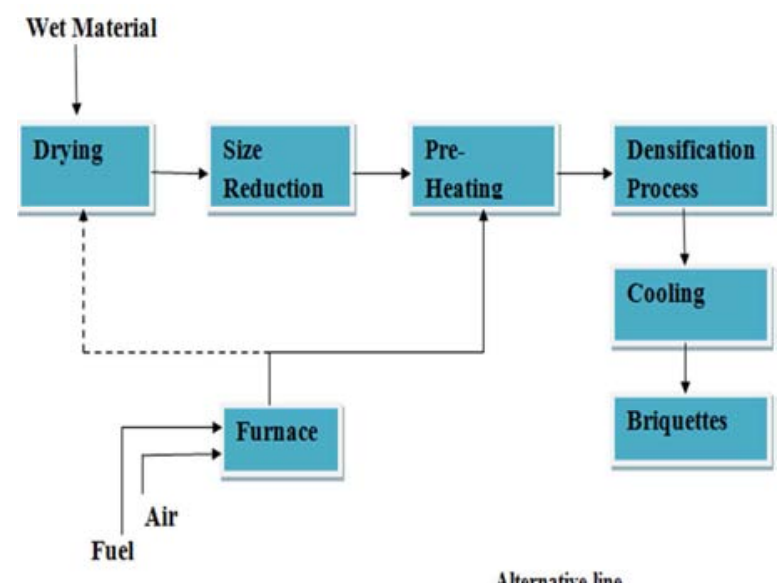

Figure 3. Flow Diagram of Briquetting Process.

\subsection{Feed Pre-Heating}

Material preparation plays a key role in the successful briquetting of biomass. Under the technical aspects, the major bottle neck for disseminating of the briquetting plant in commercial level is due to frequent wearing of the forming screw due to high friction and high power consumption during production. Some of the studies conducted earlier have revealed that the addition of heat benefits by relaxing the inherent fibers in the biomass and apparently softening its structure resulting in release of some bonding or gluing agent on to the surface.

In feed pre heating process the material is heated up to 100 ${ }^{0} \mathrm{C}$ and there is loss of moisture from $10 \%$ in feed to $8 \%$ in the product. Here furnace is used for preheating. In general feed pre heating results:

- Reduced pressure required for briquetting, resulting in reduction in power consumption

- Reduced frictional forces leading to a reduction of wear to contact parts, particularly the rotating screw

- Reduced resistance to flow leading to an enhanced rate of production.

There are different equipment's which provide direct and indirect heating system. But for biomass pre heating direct heating system is not suitable due to the combustible nature of the material. From the indirect heating systems the most appropriate for developing countries briquetting practice is to deploy high temperature thermic fluid system. The hot oil is heated in separate solid fired furnace and then circulated around the conveyer to heat the biomass [8,9, and 10]. 


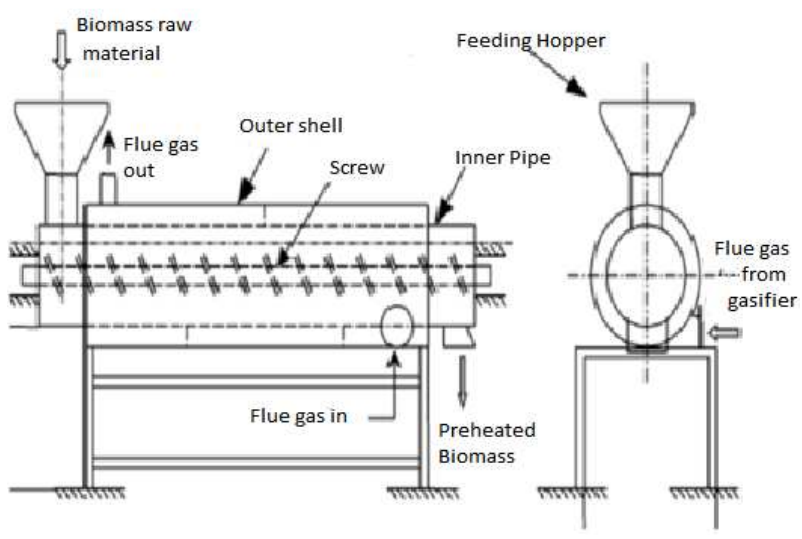

Figure 4. Saw Dust Pre-Heater.

The feed preheating system consists:

\subsubsection{A. Thermic Fluid System}

This system comprises of circulating pump, oil storage tank, furnace, piping, fittings and instruments. These heat transfer media are mineral oils which are stable up to 350 0C and are widely used for heat transfer applications. This oil is circulated between the heater/furnace and the process equipment and is a very convenient heating system requiring very little maintenance. For applications involving the heating of biomass, oil at a temperature of $2000 \mathrm{C}$ should be adequate. Normally, thermic fluid heating systems employ furnaces fired with oil and gas, but solid fuel fired systems that utilize reject briquettes and other agro-residues and allow the operating costs to be drastically reduced are most suitable for biomass briquetting.

\subsubsection{B. Furnace}

A furnace is required to heat the heat transfer oil to provide the necessary heat for preheating the biomass. In addition based on wetness of the incoming raw material, it can provide heat for flue gases in case drying of biomass is required. The design of the furnace should incorporate use of solid fuels for heating the heat transfer oils.

\subsubsection{Biomass Densification}

Biomass densification represents a set of technologies for the conversion of biomass into a fuel.

The technology is also known as briquetting and it improves the handling characteristics of the materials for transport, storing etc. Briquetting is one of several agglomeration techniques which are broadly characterized as densification technologies. Agglomeration of residues is done with the purpose of making them denser for their use in energy production. High and medium pressure compaction normally does not use any additional binder. Normally, the briquetting process bases either on screw press or piston press technology. Other briquetting technologies are less applicable in developing countries because of high investment costs and large throughputs, e.g. roller-presses to produce pellets or briquettes [2].

i. Screw press

In a screw press or screw extruder, the rotating screw takes the material from the feed port, through the barrel, and compacts it against a die which assists the build-up of a pressure gradient along the screw. Thus, the extruder features three distinct zones: feed, transport, and extrusion zones. The important forces that influence the compaction of the feed material play their role mostly in the compression zone near to the extrusion die.

Briquettes normally have a cylindrical shape although square or hexagonal shapes are possible. Outside diameter vary from 40 to $70 \mathrm{~mm}$, with typical inside hole of 15 to 25 $\mathrm{mm}$.

The frictional forces between feed materials and barrel/screw, the internal friction in the material and external heating device (of the extrusion zone) cause an increase in temperature (up to $3000 \mathrm{C}$ ), which softens the feed material. Lignin from the biomass is set free and acts as gliding and binding agent. The speed of densification, the energy consumption of the press and the quality of the briquettes produced depend on:

- Flow ability and cohesion of the feed material

- Particle size and distribution

- Surface forces

- Adhesiveness $[2,3]$.

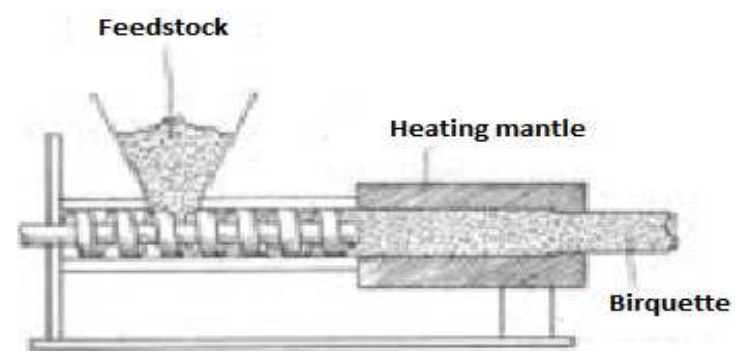

Figure 5. Screw Extruder.

The merits and demerits of this technology are:

- The output is continuous and the briquette is uniform in size.

- The outer surface of the briquette is partially carbonized facilitating easy ignition and combustion. This also protects the briquettes from ambient moisture.

- A concentric hole in the briquette helps in combustion because of sufficient circulation of air.

- The machine runs very smoothly without any shock load.

- The machine is light compared to the piston press because of the absence of reciprocating parts and flywheel.

- The machine parts and the oil used in the machine are free from dust or raw material contamination. The power requirement of the machine is high compared to that of piston press $[2,4]$.

ii. Piston Press

The material is fed into a compression chamber where a moving piston forces the material through a slightly taper die. As the material is forced through the die, frictional energy is dissipated, causing the temperature of material to rise beyond the level needed to activate the lignin as a binder. Heat is 
mainly generated at the outer surface of the briquette. Heat mainly generated as the outer surface of the briquette. Briquettes are building up of layers formed by each stroke of the piston and the briquettes can be broken in to the original by hand. Combustion and mechanically quality is therefore not very good.

The working pressure of hydraulic piston press is lower. Hence the quality and density of the produced briquette is lower. In addition the technology is rather complicated and high initial investment and some technical infrastructures are required.

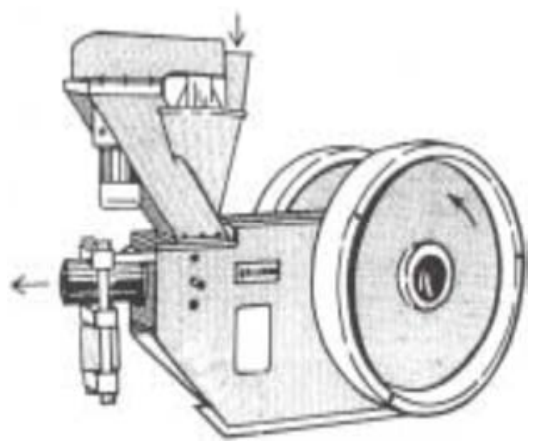

Figure 6. Mechanical Piston Briquetting Press.

The merits and demerits of this technology are:

- There is less relative motion between the ram and the biomass hence, the wear of the ram is considerably reduced.

- It is the most cost-effective technology currently offered by the Indian market.

- Some operational experience has now been gained using different types of biomass.

- The moisture content of the raw material should be less than $12 \%$ for the best results.

- The quality of the briquettes go down with an increase in production for the same power

- Carbonization of the outer layer is not possible. Briquettes are somewhat brittle.

iii. Hand Mould Briquetting

Hand moulds are the simplest devices to form small quantities of briquettes. This is a low pressure compaction used to produce households cooking fuels. It is produced from any waste biomass and binding agents. There are various binding agents in use: organic binders (Molasses, Coal tar, Bitumen, and Starch) and inorganic binders (Clay, Cement, Lime, and Sulfite liquor).

\subsubsection{Selection of Appropriate Biomass Briquetting Technology}

As it stated in the above the principal raw material input for the briquetting plant is the process byproduct of the Maichew Particle Board factory. Maichew particle board factory uses eucalyptus tree as a raw material to produce a three layer particle board. In the material preparation section there is emission of saw dust particle in the screen where the surface material and core material are got separated. This is captured in an exhaust system connected to a cyclone. The under size particles emitted in the preparation section is estimated to be about 1800 ton per year. On the other hand after pressing, the boards are cooled prior to stacking. The $75 \%$ produced particleboard panels are sanded and trimmed to final dimensions. During sanding there is also high emission of particulate matter which is controlled in the same manner as particles from the screen. This is estimated to be about 1550 ton per year.

These saw dust particles are simply captured and collected to control atmospheric emissions, but currently there is no any technology which converts the recovered dust as a byproduct fuel for a boiler or dryer or any other valuable product. Rather it is continuously damped in the compound and now days it become a potential hazard of firing for a boiler or dryer or any other valuable product. Rather it is continuously damped in the compound and now days it become a potential hazard of firing.

There are different high compaction technologies or binder less technology, consists of the piston press and the screw press, which convert the biomass residue to high quality briquetting products. At present, screw press and piston press technologies are becoming more important commercially. In a screw extruder press, the biomass is extruded continuously by a screw through a heated taper die. In a piston press the wear of the contact parts e.g., the ram and die is less compared to the wear of the screw and die in a screw extruder press. The power consumption in the former is less than that of the latter. But in terms of briquette quality and production procedure screw press is definitely superior to the piston press technology. The central hole incorporated into the briquettes produced by a screw extruder helps to achieve uniform and efficient combustion and, also, these briquettes can be carbonized. Table: 2 show a comparison between a screw extruder and a piston press $[5,6]$.

Table 3. Merits and demerits of piston press and screw press.

\begin{tabular}{lll}
\hline & Piston press & Screw extruder \\
\hline Optimum moisture content of raw material & $10-15 \%$ & $8-9 \%$ \\
Wear of contact parts & low in case of ram and die & high in case of screw \\
Output from the machine & in strokes & continuous \\
Power consumption & $50 \mathrm{kWh} / \mathrm{ton}$ & $60 \mathrm{kWh} / \mathrm{ton}$ \\
Density of briquette & $1-1.2 \mathrm{gm} / \mathrm{cm}^{3}$ & $1-1.4 \mathrm{gm} / \mathrm{cm}^{3}$ \\
Maintenance & High & Low \\
Combustion performance of briquettes & Not so good & Very good \\
Carbonization to charcoal & Not possible & Make good charcoals \\
Suitability in gasifies & Not suitable & Suitable \\
Homogeneity of briquettes & Nonhomogeneous & Homogeneous \\
\hline
\end{tabular}


As it has been seen from the above comparison the mechanical or hydraulic piston press technology is rather complicated and high initial investment and some technical infrastructures are required. In addition the quality and density of the briquettes is lower. So, the appropriate technology for this package is a screw press briquetting machine with die heater stove.

\section{Preliminary Process Design}

\subsection{Design Basis}

- Annual saw dust generation 3360 ton per year

- Operating days per year $=300$

- Operating hours per day $=16$

- Moisture content of the saw dust is $8 \%$. Therefore, it does not need drying

- $1 \%$ Loss of raw material during feed processing

- $11 \mathrm{gm} / \mathrm{kg}$ of briquette material is converted into volatile fumes i.e., $1.1 \%$ loss of material having $3.5 \%$ moisture and

- In preheating and briquetting sub system there is $2 \%$ and $2.5 \%$ loss of moisture content.

\subsection{Material and Energy Balance}

From the above explained, it is decided the operating system and the technology to convert a dried saw dust to briquetting. The ideal representation of the plant to make material balance is:

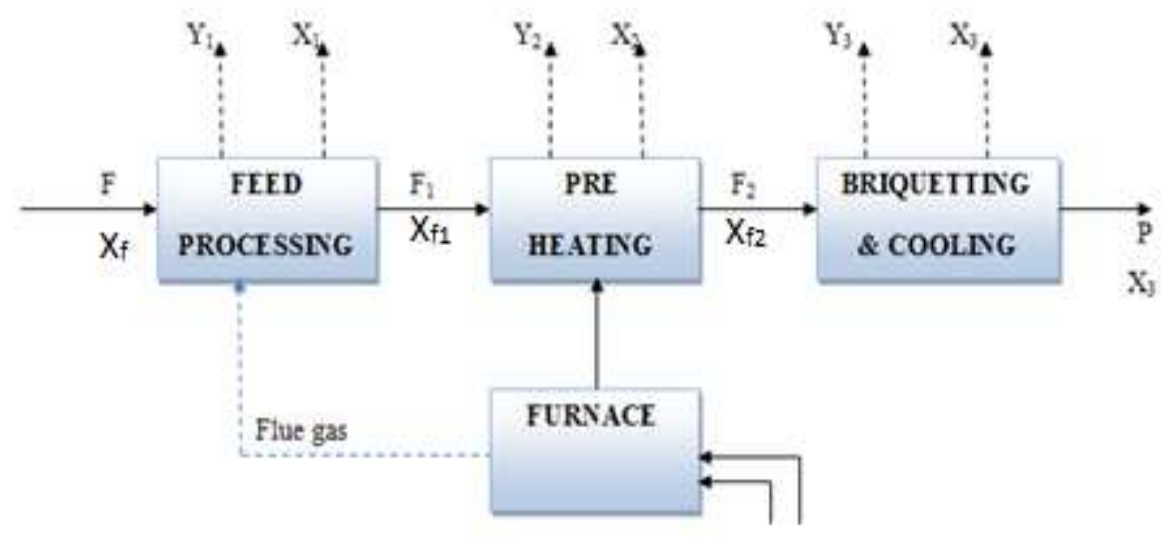

Fuel Air

Figure 7. Schematic Diagram of Ideal Briquetting Plant.

Overall material balance is given by the following equation:

Output briquettes $=$ Feed raw material - material loss in pre and briquetting process - Moisture loss in

Pre heater \& briquetting process

$$
\mathrm{P}=\mathrm{F}-\sum \mathrm{X}-\sum \mathrm{Y}(\mathrm{Kg} / \mathrm{hr})
$$

Where, $\mathrm{F}=$ feed rate with $\mathrm{Xf}$ moisture content

$\mathrm{X} 1,2,3=$ moisture loss from components

$\mathrm{Y} 1,2,3=$ material loss from components

$\mathrm{P}=$ net production of briquettes

$(\mathrm{Xf}),(\mathrm{Xf1}),(\mathrm{Xf} 2),(\mathrm{Xf3})=$ moisture content of different streams on wet basis

Feed Processing Subsystem (1)

Basis: $F=700 \mathrm{~kg} / \mathrm{hr}$ of dry feed containing $\mathrm{X}_{\mathrm{f}}=8 \%$ fraction of moisture content

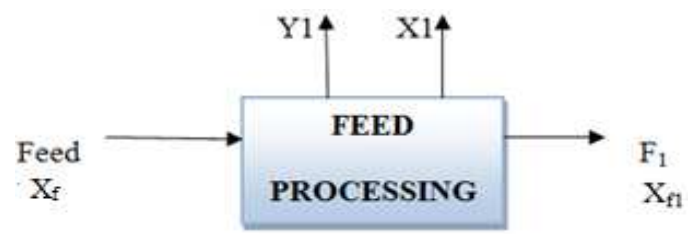

Because of the moisture content of the feed is less than $10 \%$, it doesn't need drying rather there may be loss of material during sieving.

Assume in the feed processing there is $1 \%$ loss of material.

$\mathrm{F}_{1}=0.99(\mathrm{~F}-\mathrm{X} 1)$ assume $\mathrm{X}_{1}=0$, because no drying is required

$$
\begin{aligned}
& \mathrm{F}_{1}=693 \mathrm{Kg} / \mathrm{hr} \\
& \mathrm{Y}_{1}=7 \mathrm{Kg} / \mathrm{hr} \\
& \text { Pre-heating Subsystem }
\end{aligned}
$$

\section{Pre-heating Subsystem}

In this section the biomass is heated to about $100{ }^{0} \mathrm{C}$. About $2 \%$ loss of moisture i.e. from $8 \%$ to $6 \%$ is expected [ 5 , 7]. Input is:

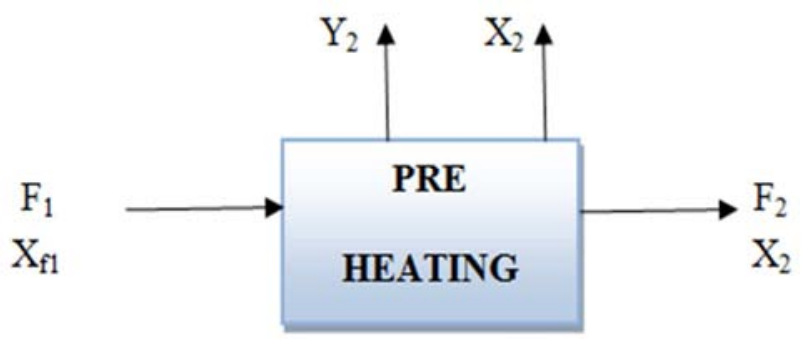


$\mathrm{F}_{1}=693 \mathrm{Kg} / \mathrm{hr}$ at $8 \%$ moisture content and there is no dry material loss $\mathrm{Y}_{2}=0$.

Loss of moisture content

$$
\begin{gathered}
X_{2}=F_{1} * \mathrm{X} f_{1}-\left(F_{1}-X_{2}\right) * \mathrm{X} f_{2} \\
X_{2}=693 * 0.08-\left(693-X_{2}\right) * 0.06 \\
X_{2}=13.07 \mathrm{Kg} / \mathrm{hr}
\end{gathered}
$$

$F_{2}=F_{1}-X_{2}$

$F_{2}=693 \mathrm{Kg} / \mathrm{hr}-13.07 \mathrm{Kg} / \mathrm{hr}$

$F_{2}=693 \mathrm{Kg} / \mathrm{hr}-13.07 \mathrm{Kg} / \mathrm{hr}$

$F_{2}=679.3 \mathrm{Kg} / \mathrm{hr}$

Briquetting and Cooling Subsystem

During processing of biomass in this subsystem, the moisture is further reduced from $6 \%$ to $3.5 \%$ and $11 \mathrm{gm} / \mathrm{kg}$ of briquette material is converted into volatile fumes i.e., $1.1 \%$ loss of material having $3.5 \%$ moisture.

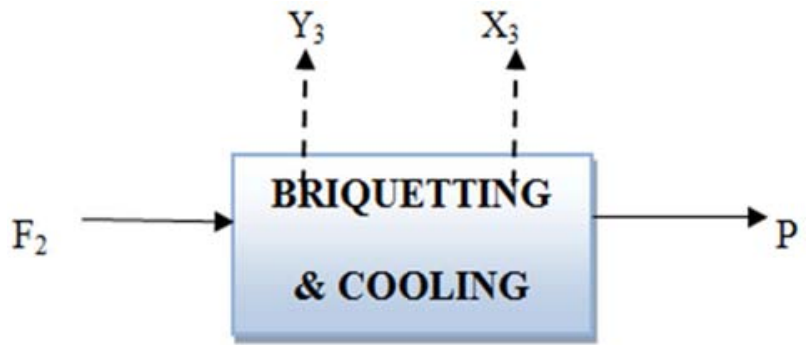

Input $\mathrm{F}_{2}=679.3 \mathrm{Kg} / \mathrm{hr}$ and there is no dry material loss $\mathrm{Y}_{3}$ $=0$

Loss of moisture content $\mathrm{X}_{4}$

$$
\begin{gathered}
X_{4}=F_{2} * X f_{2}-\left(F_{2}-X_{3}\right) * X f_{3} \\
X_{4}=679.3 * 0.06 \mathrm{Kg} / \mathrm{hr}-(679.3-X 3) * 0.035 \mathrm{Kg} / \mathrm{hr} \\
X_{4}=8.386 \mathrm{Kg} / \mathrm{hr}
\end{gathered}
$$

Loss of material due to emission of volatile fume during briquetting is $11 \mathrm{gm} / \mathrm{kg}$ per briquette material.

Product $P=F_{2}-X_{3}-P * 0.011$

$$
\begin{gathered}
P=679.3-8.386-0.011 * P \\
P=663.61 \frac{\mathrm{Kg}}{\mathrm{hr}}
\end{gathered}
$$

\subsection{Energy Balance}

As it has stated in the above the incoming waste raw material is dried enough for briquetting process. Thus, it doesn't need to incorporate a drier in its process. The furnace is only used for pre heating sub system only. The material is heated up to $800 \mathrm{C}$ and there is loss of about $2 \%$ moisture content during pre-heating.

Basic energy requirements for wood and water heating may be divided into several areas. In general, energy use in drying consists of latent heat of evaporation, sensible heat, heat lost by exhausting of air and heat lost by convection and radiation from the dryer's walls, and other heat losses such as leaks [6].
The latent heat of vaporization can be also calculated from the Clausius Clapeyron Equation in differential form which is stated as (adapted from Flowers and Mendoza 1970 as cited in Humphrey \& Bolton, 1989):

$$
H_{v}=X_{2} *\left(2.5^{11} \times 10^{6}-2.48 \times 10^{3}\right) . \mathrm{T}
$$

$\mathrm{H}_{\mathrm{V}}=$ latent heat of water $\left(\mathrm{J} / \mathrm{kg} \mathrm{H} \mathrm{H}_{2} \mathrm{O}\right)$

$\mathrm{T}=$ evaporation temperature $\left({ }^{0} \mathrm{C}\right)$

$\mathrm{X}_{2}=$ evaporated water from pre heater $(\mathrm{Kg} / \mathrm{hr})$

Mathematically, the sensible heating for drying of biomass may be expressed as

$$
\Delta H_{s}=F_{1} * C_{B M} * \Delta T
$$

$\Delta \mathrm{HS}=$ sensible heat $(\mathrm{KJ} / \mathrm{Kg}), \mathrm{CBM}=$ specific heat of biomass $(\mathrm{KJ} / \mathrm{Kg} . \mathrm{K}), \Delta \mathrm{T}=$ temperature change from ambient to evaporation temperature $\left({ }^{0} \mathrm{~F}\right)$, and $\mathrm{F}_{1}=$ feed flow rate to the pre heater $(\mathrm{Kg} / \mathrm{hr})$

Assumptions:

- Only 50\% heat going for preheating

- The remaining 50\% accounted for by losses in flue gases $(40 \%)$ and losses due to radiation in oil circulating system $(10 \%)$,

- $\quad 90 \%$ combustion efficiency of furnace which takes into consideration the radiation losses from furnace and uncombusted fuel,

- Ambient temperature 240C

Heat required in pre-heater

$$
\begin{gathered}
Q=H_{v}+\Delta H_{S} \\
Q=X_{2} *\left(2.5^{11} \times 10^{6}\right)-\left(2.48 \times 10^{3}\right) \cdot T+F_{1} * C_{B M} * \Delta T
\end{gathered}
$$

Where biomass with $10 \%$ moisture content specific heat is $1.5466 \mathrm{KJ} / \mathrm{kg}^{*} \mathrm{~K}$ (biomass briquetting technology and practices, P.D. Grover \& S.K. Mishra April 1996)

$$
\begin{gathered}
Q=13.07 *\left(2.511 \times 10^{6}-2.48 \times 10^{3}\right) \\
100+693 * 1.5466 *(353-297) \\
Q=89597.86 \mathrm{KJ} / \mathrm{hr} \\
Q=104686.49 / 0.5 \mathrm{KJ} / \mathrm{kg} \\
Q=179195.72 \mathrm{KJ} / \mathrm{kg}
\end{gathered}
$$

If it assumes $90 \%$ furnace combustion efficiency, the amount of energy required in furnace for pre heating is:

$$
\begin{gathered}
Q=179195.72 / 0.9 \mathrm{KJ} / \mathrm{kg} \\
Q=199106.35 \mathrm{KJ} / \mathrm{hr}
\end{gathered}
$$

If it assumes to use a eucalyptus saw dust briquetting briquette or any biomass with calorific value of 2500 $\mathrm{Kcal} / \mathrm{kg}$, the amount of briquetting required to pre heating sub system is calculated as follow:

Total heat duty per year

$$
\begin{gathered}
Q=199106.35 \mathrm{KJ} / \mathrm{hr} * 16 \mathrm{hr} / \text { day } * 300 \text { days } / \text { year } \\
Q=955710 \mathrm{MJ} / \text { year }
\end{gathered}
$$


Calorific value of briquettes $=10450 \mathrm{KJ} / \mathrm{kg}$

Amount of briquettes required per year

$=955710 \mathrm{MJ} /$ year $/ 10450 \mathrm{KJ} / \mathrm{Kg}$

$=91455 \mathrm{Kg} /$ year

\section{Design and Equipment Sizing}

The improved briquetting system developed recently consists of the following: a briquetting machine (screw press), a biomass pre-heater, a biomass-fired die-heating stove and a smoke removal system.

\subsection{Preliminary Pre Heater Design}

Pre-heating biomass before extrusion reduces briquetting energy consumption and also extends the life of the briquetting screw.

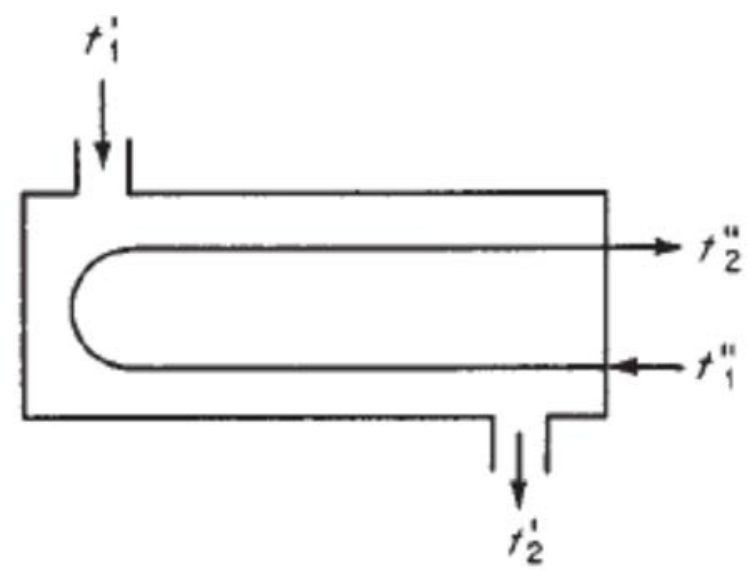

Figure 8. Schematic Diagram of Heat Exchanger

Therefore, a pre-heater was incorporated in the briquetting package.

The biomass pre-heater essentially consists of two concentric pipes. Biomass is passed through the inner pipe under the action of a screw rotated by a variable speed motor. The raw material is pre-heated while being conveyed through the inner pipe by circulating hot termic oil at 1700c and temperature drop within the heat exchanger is $100 \mathrm{C}[2,9]$.

The rate of heat transfer from hot oil to biomass is affected by individual transfer coefficients on the oil and biomass sides; and to some extent on the thermal resistance of shell thickness, but the controlling transfer resistance is on the biomass side. This is due to the low packing density and the refractory nature of biomass materials [4]. The following data are operational characteristics:

- Total heat duty $=89597.86 \mathrm{KJ} / \mathrm{hr}$

- Feed inlet temperature $=240 \mathrm{C}$

- Feed out let temperature $=800 \mathrm{C}$

- Hot oil inlet temperature $=1700 \mathrm{C}$
- Hot oil out let temperature $=1600 \mathrm{C}$

- Overall heat transfer coefficient $=0.03486 \mathrm{KW} / \mathrm{m}^{2} * \mathrm{~K}$

$\mathrm{Q}=U A \Delta T_{l m}$ Where $\mathrm{Q}=$ Rate of heat exchange $(\mathrm{KJ} / \mathrm{hr})$

$\mathrm{U}=$ Overall heat transfer coefficient $(\mathrm{KJ} / \mathrm{m} 2 . \mathrm{K})$

$\mathrm{A}=$ Heat exchange area $\left(\mathrm{m}^{2}\right)$

$\Delta \mathrm{Tlm}=$ mean temperature difference

$$
\begin{gathered}
\mathrm{A}=\mathrm{Q} / \mathrm{U} * \Delta T_{l m} \\
\mathrm{LMTD}=\Delta T_{l m}=\frac{\left(t_{1}^{\prime}-t_{1}^{\prime \prime}\right)-\left(t_{2}^{\prime}-t_{2}^{\prime \prime}\right)}{\ln \left(\frac{t_{1}^{\prime}-t_{1}^{\prime \prime}}{t_{2}^{\prime}-t_{2}^{\prime \prime}}\right)} \\
=\Delta T_{l m}=(180-24)-(160-80) / \ln (180-24) /(160-80) \\
=\Delta T_{l m}=110^{0} C(383 \mathrm{~K}) \\
\mathrm{A}=89597.86 \mathrm{KJ} / \mathrm{hr} / 0.03486 \mathrm{KW} / \mathrm{m} 2 * \mathrm{~K} * 383 \mathrm{~K} \\
\mathrm{~A}=1.86 \mathrm{~m} 2
\end{gathered}
$$

\subsection{Screw Press Briquetting Machine Design}

The briquetting machine used in this package is a Thailand manufacture, heated die biomass screw press machine. The main components of the machine shown below is a screw which feeds the saw dust material from the feeding hopper which is driven by the main motor with $30 / 45 \mathrm{KW}$ capacity, compact it and press it in to a die of square, cylindrical, hexagonal or octagonal cross-section depending on the type die it uses.

An electrical coil is fixed on the outer surface of the die, to heat it to about $300 \square \mathrm{C}$. This temperature is required to soften the lignin in the biomass, which acts as a binder. Generally the machine has the following specifications.

General Specifications:

- Capacity: 600 - $700 \mathrm{Kg} / \mathrm{h}$ (Varies according to type of raw material \& input power)

- Main Motor: 30/45 KW (Voltage \& Speed to meet exact customer requirements)

- Agitator Motor: 0.25/1.0 KW (Depending on the raw material \& machine capacity)

- Mould Heaters: 6.0 KW (Thermocouple \& Temperature controller, included)

- Transmission: Through V Belts \& Pulley arrangement

- Speed: 450 - 750 R.P.M (Depending on the Raw Material \& Capacity of Machine)

- Profile of Moulds: Cylindrical / Hexagonal / Square or Octagonal

- Size of Briquette: $55 \mathrm{~mm} / 65 \mathrm{~mm}$ (Measured across two parallel sides) $[3,7]$. 


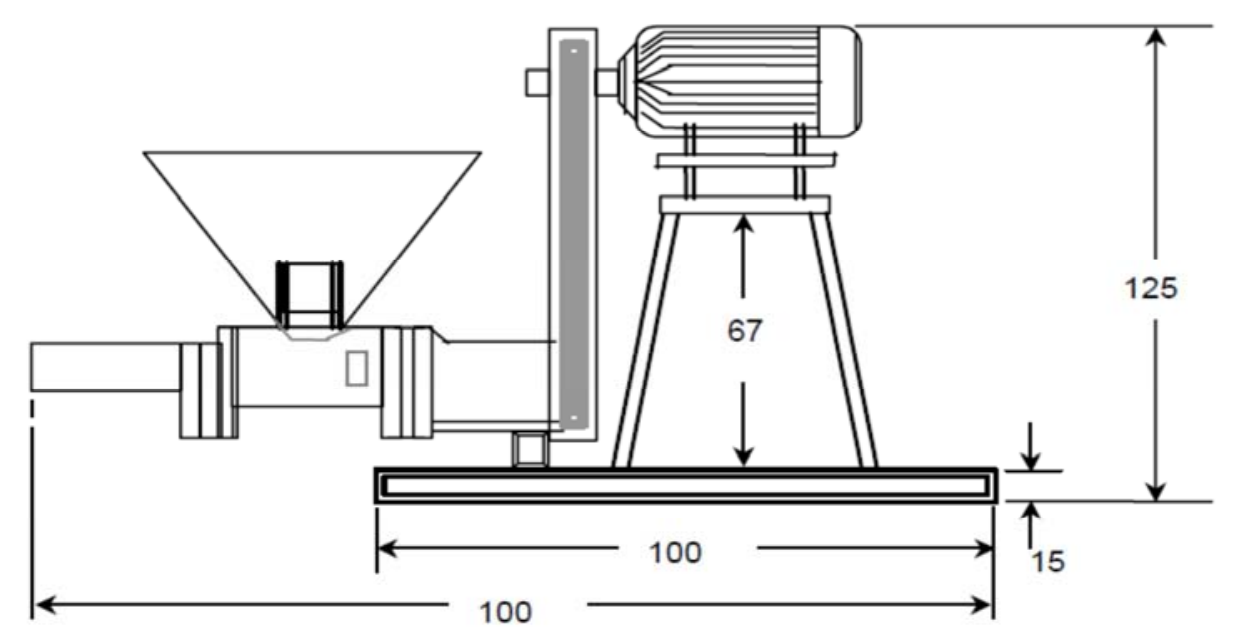

All dimensions are in $\mathrm{cm}$

Figure 9. Schematic Diagram of the Heated-Die Screw-Press Briquetting Machine.

\section{Economic Analysis of Briquetting}

\subsection{Estimation of Total Investment}

Table 4. Cost of Major Equipment.

\begin{tabular}{lll}
\hline Equipment & $\begin{array}{l}\text { Power rating } \\
\text { (horsepower, hp) }\end{array}$ & Cost (birr) \\
\hline Screw press briquetting machine & 57 & 144800 \\
Feed pre-heater & 3 & 45000 \\
Main screw conveyer & 3 & 45500 \\
Cooling conveyer & 3 & 71000 \\
Furnace & & 55000 \\
Tractor and trailer & & 200000 \\
Total & 66 & 561300 \\
\hline
\end{tabular}

Purchased equipment $=\mathrm{F}^{*}$ Cost of major equipment Where $\mathrm{F}=1.3$, is a correction factor based on wise guess

Purchased equipment cost $=729,690$ birr

Table 5. Estimation of Fixed Capital Investment (FCI).

\begin{tabular}{lll}
\hline Component & Assumed \% of FCI & Cost (birr) \\
\hline Purchased equipment & 32 & 729,690 \\
Purchased equipment installation & 5 & 114,014 \\
Instrumentation (installed) & 3 & 68,408 \\
Piping (installed) & 3 & 68,408 \\
Electric (installed) & 2 & 45,605 \\
Building (including service) & 21 & 478,859 \\
Yard improvement & 2 & 45,605 \\
\hline
\end{tabular}

\begin{tabular}{lll}
\hline Component & Assumed \% of FCI & Cost (birr) \\
\hline Service facilities (installed) & 10 & 228,028 \\
Engineering and supervision & 4 & 91,211 \\
Construction expense & 8 & 182,422 \\
Contract fee & 5 & 114,014 \\
contingency & 5 & 114,014 \\
Total (fixed capital investment) & & $2,280,281$ \\
\hline
\end{tabular}

Total capital investment $=$ fixed capital investment + working capital

Assume working capital is $10 \%$ of total capital investment

$$
\begin{gathered}
\text { TCI }=\text { FCI }+0.1 \text { TCI } \\
T C I=(2280281+228028) \text { Ethiopian Birr } \\
T C I=2,508,309 \text { Ethiopian Birr }
\end{gathered}
$$

The total capital investment which will be offered by the Machine Particle Board Company is about 2,508,309 Ethiopian Birr.

\subsection{Estimation of Total Production Cost}

Total product cost $=$ manufacturing cost + general expenses

I. Manufacturing cost $=$ direct production costs + fixed

\begin{tabular}{|c|c|c|c|}
\hline Components & & Qty/ number & Cost (birr) \\
\hline \multirow{11}{*}{$\begin{array}{l}\text { A. Direct } \\
\text { production costs }\end{array}$} & $\begin{array}{l}\text { 1. Raw materials (it is assumed that cost the dust particle is zero) } \\
\text { 2. Operating, supervisory and clerical labor }\end{array}$ & 3360 ton dust/year & 0 \\
\hline & Production head & 1 & 36000 \\
\hline & Shift leader (technician) & 2 & 57600 \\
\hline & Machine operator & 3 & 21600 \\
\hline & Mechanical \&electrical maintenance & 3 & 43200 \\
\hline & Accountant & 1 & 13000 \\
\hline & Store keeper & 1 & 9000 \\
\hline & Daily laborers & 8 & 57600 \\
\hline & Sub Total & 19 (man power) & 238000 \\
\hline & 3. Utilities & & \\
\hline & Electric power & $80 \mathrm{hp}(52 \mathrm{Kw})$ & 214848 \\
\hline
\end{tabular}
charges + plant overhead costs

Table 6. Estimation of Total Production Cost. 


\begin{tabular}{|c|c|c|c|}
\hline Components & & Qty/ number & Cost (birr) \\
\hline \multirow{7}{*}{$\begin{array}{l}\text { B. Fixed } \\
\text { Charges } \\
\text { C. Plant- } \\
\text { overhead costs }\end{array}$} & Fuel ( briquettes) & $91455 \mathrm{Kg} /$ year & 137182.5 \\
\hline & Sub Total & & 352030 \\
\hline & 4. Maintenance and Repairs and operating & & 228028 \\
\hline & 1. Depreciation $(10 \%$ of fixed-capital investment for machinery and equipment & & 228028 \\
\hline & 2. Local taxes ( $1-4 \%$ of fixed capital investment) & & 80000 \\
\hline & $\begin{array}{l}\text { (SO- } 70 \% \text { of cost for operating labor, supervision, and maintenance, or } 5-15 \% \text { of total } \\
\text { product cost); }\end{array}$ & & 90000 \\
\hline & Total & & 1216086 \\
\hline
\end{tabular}

Manufacturing Cost $=$ Direct Production + Fixed Charges + Plant Overhead Costs

Manufacturing Cost $=(238000+352030+228028)+(228028+80000)+90000$

$=1216086 \mathrm{Birr}$

The total manufacturing cost for the plant is 1216086 Ethiopian Birr.

II. General expenses $=$ administrative costs + distribution and selling costs

\begin{tabular}{ll}
\hline Component & Cost (birr) \\
\hline Administrative costs & 70000 \\
Distribution and selling costs & 80000 \\
Total & 150000 \\
\hline
\end{tabular}

General expenses $=$ Administrative costs + distribution and selling costs

$$
\begin{gathered}
\text { General expenses }=70000+80000 \\
\text { General expenses }=150000 \text { Birr }
\end{gathered}
$$

The general expenses cost of for the plant is 150000 Ethiopian Birr.

III. Total product cost $=$ manufacturing cost + general expenses

$$
\begin{gathered}
\text { Total product cost }=1216086+150000 \\
=1,381,086 \mathrm{birr}
\end{gathered}
$$

The total cost for operating the plant and selling the product is 1,381,086 Ethiopian Birr.

\subsection{Profitability Analysis}

Profit before tax $=$ revenue - total production cost

- If it assumes sell price of briquetting is $1.5 \mathrm{birr} / \mathrm{kg}$ and a capacity utilization of $75 \%$.

Total production per year

$=660 \mathrm{Kg} / \mathrm{hr} * 16 \mathrm{hr} /$ day $* 300$ day $/$ year $* 0.75$

$=2376000 \mathrm{Kg} /$ year

Revenue $=2376000 \mathrm{Kg} /$ year $* 1.5 \mathrm{birr} / \mathrm{kg}$

Revenue $=3564000 \mathrm{birr} /$ year

Profit before tax $=3564000-1381086$

Profit before tax $=2,182,913 \mathrm{birr}$

Profit after tax $=(1-t R) P B T-$ Depreciation

Where: $t R($ tax rate $)=35 \%$
Profit after tax $=(1-0.35) * 2182913-228028$

Profit after tax $=1190865.25 \mathrm{birr} /$ year

Payback period $=$ FCI $/$ Net Profit

$=2280281$ birr $/ 1190865.45$ birr $/$ year

Payback period $=1.9$ year

The above profitability analysis indicates that the total investment can return with almost two years with one single screw press machine.

\section{Conclusion}

Tough briquetting practice can offer important and substantial environmental and socio economic benefit in developing countries by remedied deforestation and fire wood shortage; it is not developed yet in a desired rate. In Ethiopia briquetting plant set up in early 1980s have failed to practice in commercial wise, mostly because of poor management skill, high power consumption and lack of technical constraints involved and the lack of knowledge to adapt the technology to suit local conditions. By alleviating such problems, the developing countries like Ethiopia can turn their huge agro and forest residue to generate energy with environmental friendly.

- As it observed in the above; from the different available briquetting technology screw press extruder with a pre heater and heated die coils has been chosen with respect to optimum energy consumption, low wear age and quality of briquettes.

- As a matter of fact the saw dust materials from different lines of Maichew Particle Board Factory are in ultimate optimum conditions for briquetting process. It doesn't incur additional cost for pretreatment like chopping and/or drying. They are at the desired range of size and moisture content $(6-8 \%)$.

- The integrate briquetting plant can turn the environmental unfriendly saw dust materials which was simply disposed to the environment to a valuable high quality briquettes with a calorific value $2800-4200$ $\mathrm{Kcal} / \mathrm{Kg}$.

- Based on the results of this study, manufacturing of briquettes from saw dust residue is feasible with 
economic benefit besides to the socio environmental benefits. It is an investment which can recover its capital with almost two years.

\section{Acknowledgements}

First of all we would like to thank God for his blessing and guidance throughout our life. We would like to thank to Asgele Gebrekidan from Maichew Particle Board Factory for his continuous offers of different current data from the company. We wonder if this project would be completed without his help. We would also to thank Sileshi Abebe from water and energy minister for his kindness in offers us different materials.

\section{References}

[1] Robert H. Perry; and Don. Green. (2007). Perry's Chemical Engineers' Handbook. 8th Edition, McGraw Hill Professional

[2] MC Cabe W. L. and J. C. Smith. (1956). Unit Operations in Chemical Engineering, pp943.
[3] Max Peters and Klaus Timmerhaus. (1991). Plant Design and Economics for Chemical Engineers. $4^{\text {th }}$ Edition, Mcgraw Hill Inc.

[4] Eriksson, S. and M. Prio., (1990).The briquetting of agricultural wastes for fuel, FA0 Environment and Energy Paper 11, FA0 of the UN, Rome.

[5] Aqa, S. and Bhattacharya, S.C. (1992). Densification of preheated sawdust for energy conservation, Energy.

[6] P. D. Grover and S. K. Mishra. (1996). Biomass Briquetting: Technology and Practices, RWEDP.

[7] S. C. Bhattacharya and S. Kumar. (2005).Technology Packages: Screw-press briquetting machines and Briquettefired stoves.

[8] http://www.ronakbriquettingmachine.com/briquettingplant.html,

[9] Pietsch, W. (1991). Size Enlargement by Agglomeration, John Wiley \& Sons Ltd., England.

[10] Reed, T.B., Trefek, G, and Diaz, L. (1980). Biomass densification energy requirements in thermal conversion solid wastes and biomass, American Chemical Society, Washington D.C. 